\title{
Gezielte Darstellung des fetalen Corpus callosum mit 3D-Ultraschall
}

\section{Targeted Depiction of the Fetal Corpus callosum with 3D-Ultrasound}

Bei der gezielten Ausschlussdiagnostik einer fetalen Hirnfehlbildung ist die Darstellung des Corpus callosum (= Balken) als elementarer Bestandteil der sonografischen Untersuchung anzusehen. Bei einem Fehlen des Balkens (=Balkenagenesie) muss nicht nur mit einer schweren körperlichen und kognitiven Behinderung des Kindes gerechnet werden, sondern auch mit unterschiedlichen Syndromen und Chromosomenaberrationen (Trisomie 13, 18 oder Triploidie).

Das Corpus callosum stellt eine große, quer verlaufende Faserverbindung zwischen den beiden Großhirnhemisphären dar. Es bildet das Dach der beiden Seitenventrikel. Über die mehr als 200 Mio. markhaltigen Nervenfasern werden Informationen von der einen Hemisphäre zur anderen übermittelt.

Anatomisch wird der Balken in 4 Bereiche untergliedert: 1. Rostrum (Schnabel), 2. Genu (Knie), 3. Truncus (Stamm) und 4. Splenium (Hinterende).

Sonografisch kann das Corpus callosum erst ab ca. 18-20 Schwangerschaftswochen (SSW) nachgewiesen werden. Ab 22 SSW sollte es auf alle Fälle darstellbar sein.

Gegenüber der 2D-Sonografie bietet die 3DSonografie insbesondere bei der Untersuchung des fetalen Gehirns große Vorteile, da sich mit den unterschiedlichen Darstellungsmodi die verschiedenen Hirnebenen präzise einstellen lassen.

In der multiplanaren Demonstration, bei der alle 3 senkrecht aufeinander stehenden Schnittebenen gleichzeitig auf dem Monitor dargestellt werden, lässt sich die Medianebene ( $\bullet$ Abb. 1a) gezielt einsehen und das Corpus callosum im Längsschnitt darstellen. Mit dem Oberflächenmodus lässt sich die mediane Schnittfläche des Gehirns räumlich demonstrieren ( $\odot \mathbf{A b b}$. 1b). Dadurch kommen die Hirnstrukturen, wie das Corpus callosum, noch deutlicher als im 2D-Bild zum Vorschein.

Mit dem Glass-Body-Modus, einer Kombination aus 3D-Grauwert- und 3D-FarbdopplerTechnik gelingt zusätzlich die Darstellung der A. pericallosa ( $\triangle$ Abb. 1c), die zwischen den Großhirnhemisphären am Oberrand des Corpus callosum entlang zieht. Der fehlende Nachweis der A. pericallosa erhärtet den Verdacht einer Corpus-callosum-Agenesie.

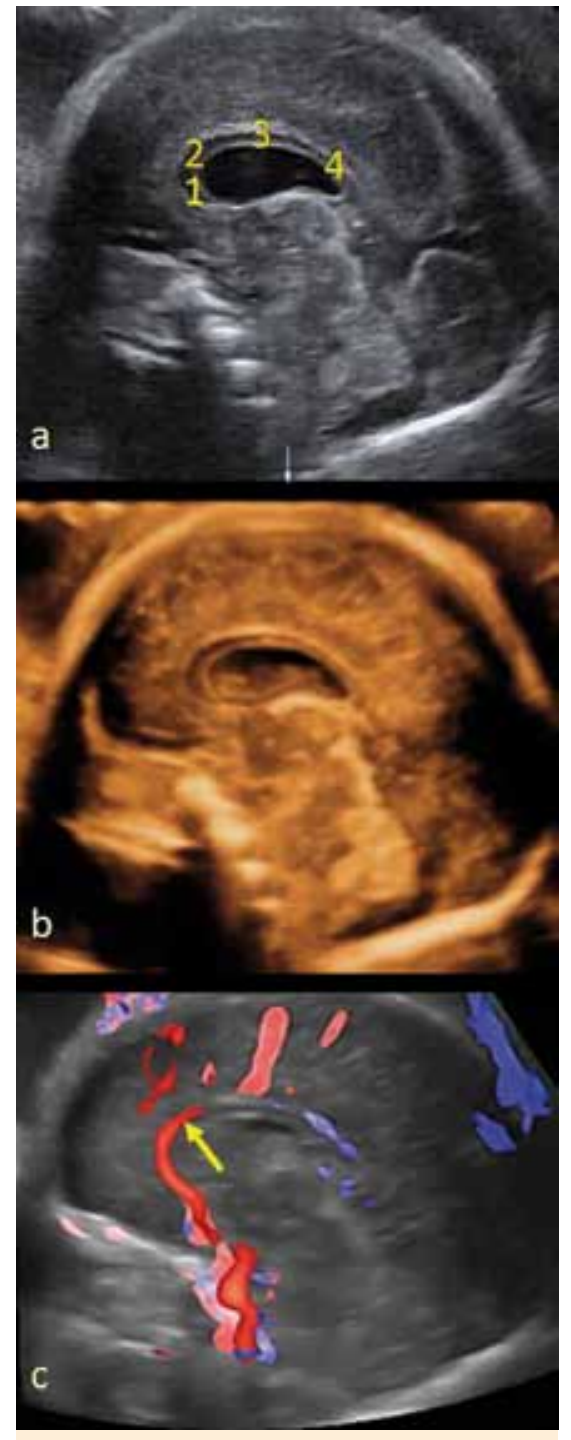

Darstellung des Corpus callosum mit 28+0 SSW. a Demonstration des Corpus callosum mit der 3D-Multiplanartechnik (hier isolierte 2D-Darstellung der Medianebene). 1 = Rostrum, 2 = Genu, 3 = Truncus, 4 = Splenium. b Räumliche Darstellung der medianen Schnittfläche mit dem 3D-Oberflächenmodus. c 3D-Glass-Body-Modus mit Demonstration $\operatorname{der}$ A. pericallosa (Pfeil).

Depiction of the corpus callosum with $28+0$ GW. a Demonstration of the Corpus callosum with 3D-multi-plain technique (here 2D-depiction of the median plain). 1 = rostrum, 2 = genu, 3 =truncus, $4=$ splenium.

b three dimensional depiction of the median plain with 3D-surface mode.

c 3D-Glass body-mode with demonstration of the A. pericallosa (arrow).
In the directed diagnostics of ruling out fetal cerebral malformations the depiction of the Corpus callosum is considered a rudimentary element of ultrasonographic examination.

With the absence of the corpus callosum (= corpus callosum agenesia) not only do severe physical and mental disabilities, but also different kinds of syndromes and chromosome aberations (trisomy 13,18 or triploidy) have to be considered.

The corpus callosum represents a vast transversely running fibrous connection between the two cerebral hemispheres. It also composes the roof of both lateral ventricles. Over 200 million myelinated nerve fibres conduct information from one hemisphere to the other.

Anatomically the corpus callosum is divided into 4 sections: 1 . rostrum (beak), 2 . genu (knee), 3. truncus (stem) and 4. splenium ( heel). Sonographically the corpus callosum can only be detected from the 18.-20. gestational week (GW). It should certainly be portrayable as of the 22. GW. In contrast to 2D- sonography 3D-sonography presents many benefits especially when examining the fetal brain, because the different cerebral plains can be displayed with various display modes.

In multi-plain demonstration all 3 plains, which are perpendicular to one another are displayed simultaneously on the monitor and the median plain ( $\odot$ Fig. 1a) can be specifically viewed and the corpus callosum can be portrayed in longitudinal section.

With the surface mode the median plain of the brain can be demonstrated ( $\bullet$ Fig. 1b). Thus, encephalic structures like the corpus callosum are revealed more clearly than in 2D-sonography.

With the help of the Glass body-mode, a combination of 3D-grey level- and 3D-colour doppler-techinique, the A. pericallosa ( $\odot$ Fig. 1c) can be displayed, which runs between the 2 cerebral hemispheres on the upper margin of the corpus callosum. The absence of the A. pericallosa substantiates the suspicion of corpus callosum agenesia.

\section{E. Merz, Frankfurt/Main} emerz@mail.uni-mainz.de 